\title{
Effect of ammonium on nitrate utilization by Emiliania huxleyi, a coccolithophore from the oceanic northeastern Pacific
}

\author{
Diana E. Varela*, Paul J. Harrison \\ Department of Earth and Ocean Sciences, University of British Columbia, Vancouver, British Columbia V6T 124, Canada
}

\begin{abstract}
Explanations for the high nitrate $\left(\mathrm{NO}_{3}{ }^{-}\right)$, low phytoplankton biomass of the subarctic NE Pacific have mainly centered on iron limitation and grazing pressure. Although ammonium $\left(\mathrm{NH}_{4}{ }^{+}\right)$has been proven to inhibit $\mathrm{NO}_{3}{ }^{-}$uptake by phytoplankton in numerous laboratory and field studies, this hypothesis has not been experimentally tested for the subarctic Pacific. The effect of increasing $\mathrm{NH}_{4}{ }^{+}$ concentrations on $\mathrm{NO}_{3}^{-}$uptake by Emiliania huxleyi, a coccolithophore isolated from Ocean Station Papa in the subarctic NE Pacific, is examined. The effect of diel periodicity on $\mathrm{NO}_{3}{ }^{-}$uptake and other physiological parameters for E. huxleyi during a $14: 10 \mathrm{~h}$ light:dark cycle are also reported. About $84 \%$ of the total daily $\mathrm{NO}_{3}{ }^{-}$was taken up during the light period. Cell division occurred only during the last part of the dark period. Chlorophyll $a$, nitrogen, and carbon quotas and cell volume increased during the light period and decreased during the dark. The presence of $\mathrm{NH}_{4}{ }^{+}$inhibited $\mathrm{NO}_{3}$ uptake in E. huxleyi. Nitrate uptake rates were reduced to half the maximum value at $0.24 \mu \mathrm{M} \mathrm{NH}_{4}{ }^{+}$, and maximum realized inhibition was $-100 \%$ at $2.2 \mu \mathrm{M} \mathrm{NH}_{4}{ }^{+}$If this laboratory result is extrapolated to field conditions, the inhibition of $\mathrm{NO}_{3}^{-}$uptake rates for the small size class of phytoplankton would be predicted to be 38 to $70 \%$ for the range of ambient $\mathrm{NH}_{4}{ }^{+}$concentrations found in the oceanic NE Pacific.
\end{abstract}

KEY WORDS: Nitrate uptake A Ammonium inhibition - Diel periodicity - Emiliania huxleyi - Ocean station Papa - northeastern Pacific - HNLC

\section{INTRODUCTION}

Numerous studies have shown that $\mathrm{NH}_{4}{ }^{+}$exerts an effect on the $\mathrm{NO}_{3}{ }^{-}$metabolism of marine algae. Ammonium has been found to be the preferred nitrogen source for most species of marine phytoplankton as well as to inhibit the utilization of $\mathrm{NO}_{3}{ }^{-}$in a more direct manner (see review by Dortch 1990). Concentrations of $\mathrm{NH}_{4}{ }^{+}$lower than $1 \mu \mathrm{M}$ may readily inhibit $\mathrm{NO}_{3}{ }^{-}$uptake (e.g. McCarthy et al. 1975, Harrison et al. 1996). However, in some cases $\mathrm{NH}_{4}{ }^{+}$had little or no effect on $\mathrm{NO}_{3}{ }^{-}$ uptake (e.g. Kokkinakis \& Wheeler 1987, Kristiansen \& Lund 1989) and in other cases $\mathrm{NH}_{4}{ }^{+}$enhanced $\mathrm{NO}_{3}{ }^{-}$ uptake rates (e.g. Dortch et al. 1991). Therefore, although there is undoubtedly an interaction between $\mathrm{NH}_{4}{ }^{+}$and $\mathrm{NO}_{3}{ }^{-}$uptake, it appears that the extent and threshold concentrations involved depend on the spe-

\footnotetext{
•E-mail:varela@unixg.ubc.ca
}

cies under study, its physiological status, and the environmental conditions to which this particular species or the natural assemblage of phytoplankton has been exposed (e.g. Bates 1976, Dortch \& Conway 1984, Dortch et al. 1991, Harrison et al. 1996, Lomas \& Glibert 1999).

In the oceanic subarctic NE Pacific, concentrations of $\mathrm{NO}_{3}{ }^{-}$are high while $\mathrm{NH}_{4}{ }^{+}$concentrations are low and fairly constant annually. Surface concentrations of $\mathrm{NO}_{3}{ }^{-}$are rarely below $5.0 \mu \mathrm{M}$ and those of $\mathrm{NH}_{4}{ }^{+}$range between 0.17 and $0.54 \mu \mathrm{M}$ at Ocean Station Papa (OSP; $50^{\circ} \mathrm{N}, 145^{\circ} \mathrm{W}$; Varela \& Harrison 1999). Despite the high $\mathrm{NO}_{3}{ }^{-}$concentrations, phytoplankton biomass remains low even during times of the year when environmental conditions are favorable for rapid growth (Varela \& Harrison 1999). A number of factors have been cited as responsible for the low rates of $\mathrm{NO}_{3}{ }^{-}$ uptake, such as iron limitation and grazing pressure (e.g. Martin \& Fitzwater 1988, Frost 1991, Miller et al. 1991, Boyd et al. 1996). Wheeler \& Kokkinakis (1990) 
added a new candidate: $\mathrm{NH}_{4}{ }^{+}$inhibition of $\mathrm{NO}_{3}{ }^{-}$ uptake. They suggested that the constant recycling of $\mathrm{NH}_{4}{ }^{+}$in subarctic waters can also limit the utilization of $\mathrm{NO}_{3}{ }^{-}$by phytoplankton, and thus prevent its depletion. However, their conclusions were only based on the field observation that $\mathrm{NO}_{3}{ }^{-}$uptake rates decreased with increasing ambient $\mathrm{NH}_{4}{ }^{+}$concentrations. This observation deserves further testing both in the field and in the laboratory under conditions that simulate the natural environment and with unialgal cultures of ecologically relevant species isolated from subarctic waters.

Numerous physiological studies have focused their attention on the coccolithophore Emiliania huxleyi (Class Prymnesiophyceae) because of its great importance in global nutrient cycles (e.g. Keller et al. 1989, Sikes \& Fabry 1994). E. huxleyi has been found to be the most abundant coccolithophore in surface waters of the oceanic subarctic NE Pacific (Honjo \& Okada 1974) and forms part of the dominant $<5$ um autotrophic size class (Taylor \& Waters 1982, Booth et al. 1993, Varela 1997). The majority of studies on $E$. huxleyi, however, have been conducted on isolates obtained from the North Atlantic (e.g. Brand 1982), because until recently isolates from the oceanic NE Pacific or any other high nitrate, low chlorophyll (HNLC) region have not been available. In November of 1991, E. huxleyi was successfully isolated from water samples from OSP in the oceanic NE Pacific (see Muggli 1995). Since then, experiments on this isolate have focused mainly on metal nutrition (Muggli 1995) and sinking rates (Lecourt et al. 1996). Further studies are needed to understand other physiological aspects, such as the nitrogenous nutrition, of this coccolithophore from a HNLC region.

The main purpose of the present study was to investigate the effect of increasing $\mathrm{NH}_{4}{ }^{+}$concentrations on $\mathrm{NO}_{3}{ }^{-}$uptake rate in Emiliania huxleyi grown under environmental conditions that simulated those of the oceanic NE Pacific. The diel periodicity of $\mathrm{NO}_{3}{ }^{-}$uptake rate and other physiological characteristics by E. huxleyi are also presented.

\section{MATERIALS AND METHODS}

Culture conditions and measurements. Recently isolated cells of Emiliania huxleyi had multiple layers of coccoliths, and, in order to preserve the original morphology, E. huxleyi has been maintained in nutrientenriched microwave-sterilized OSP water since November 1991 (Muggli 1995). The maintenance medium was enriched with macronutrients $\left(30 \mu \mathrm{M} \mathrm{NO}_{3}{ }^{-}\right.$and $5 \mu \mathrm{M} \mathrm{HPO}_{4}{ }^{2-}$ ), metals (23 nM Mn, $8 \mathrm{nM} \mathrm{Zn,} 1 \mathrm{nM} \mathrm{Cu}$, $2.5 \mathrm{nM} \mathrm{Co}, 100 \mathrm{nM} \mathrm{Mo}, 10 \mathrm{nM}$ Se and $100 \mathrm{nM} \mathrm{Fe}$ ), EDTA $(10 \mu \mathrm{M})$ and vitamins $\left(1 \times 10^{-4} \mathrm{~g}^{-1}\right.$ thiamine and
$5 \times 10^{-7} \mathrm{~g} \mathrm{l}^{-1}$ biotin) (Muggli 1995). Cultures were maintained at $16^{\circ} \mathrm{C}$ under low irradiance (ca $30 \mu \mathrm{mol}$ photons $\mathrm{m}^{-2} \mathrm{~s}^{-1}$ provided by Vita-lite ${ }^{\mathrm{TM}}$ fluorescent tubes and measured with a Biophysical Instruments Inc. light meter, model QSL 100) on a 14:10 h light:dark (L:D) cycle.

Experimental cultures were established under environmental conditions that simulated the natural oceanic environment of Emiliania huxleyi for the summer period. Cells were grown in semi-continuous batch cultures with filter-sterilized $(0.22 \mu \mathrm{m})$ nutrientenriched artificial seawater medium (ESAW; Harrison et al. 1980) in 1 or 21 acid-clean glass flasks. The original ESAW was modified by reducing the concentrations of $\mathrm{Fe}, \mathrm{Mn}, \mathrm{Zn}, \mathrm{Co}$ and EDTA by a factor of 50 , adding $1.2 \mathrm{nM} \mathrm{Ni}, 1.2 \mathrm{nM} \mathrm{Mo}$, and $10 \mathrm{nM}$ Se, decreasing the concentrations of $\mathrm{NO}_{3}{ }^{-}$to $30 \mu \mathrm{M}$ and $\mathrm{HPO}_{4}{ }^{2-}$ (as $\mathrm{Na}_{2} \mathrm{HPO}_{4}$ ) to $3 \mu \mathrm{M}$, and omitting Si. Cultures were exposed to saturating irradiance (ca $180 \mu \mathrm{mol}$ photons $\mathrm{m}^{-2} \mathrm{~s}^{-1}$; Muggli \& Harrison 1996) with a $14: 10 \mathrm{~h} \mathrm{~L}: \mathrm{D}$ cycle while immersed in a temperature-regulated water bath maintained at $10.5 \pm 0.5^{\circ} \mathrm{C}$. Cultures were manually agitated once or twice daily, and were not exposed to bubbling in order to avoid contamination by $\mathrm{NH}_{4}{ }^{+}$from the air. The concentration of total dissolved inorganic carbon (DIC) in the cultures was measured with an ADC type $225 \mathrm{Mk} 3$ infra-red gas analyser during the logarithmic phase of growth. DIC values ranged between 1.92 and $2.05 m \mathrm{M}$, close to the typical DIC concentration in the oceans (i.e. around $2 \mathrm{mM}$ ). The $\mathrm{pH}$ of the medium was measured frequently and found to range between 7.9 and 8.1. Cells were acclimated to the described conditions for $>10$ generations.

Cell growth in the experimental cultures was monitored daily ( $9 \mathrm{~h}$ after the start of the light period) using cell counts and in vivo fluorescence. All culture transfers and sampling were conducted in mid-logarithmic growth phase. Cultures were transferred when cell densities approached $240 \times 10^{3}$ cells $\mathrm{ml}^{-1}$ (every $5 \mathrm{~d}$ on average) and were generally diluted 10 -fold. Microscopic examination of the cultures was done at the time of the transfers to ensure that the morphology of the cells, mainly in terms of coccolith abundance, remained unchanged for the entire experiment. Cultures were discarded if the number of layers of coccoliths on the cells was decreasing in any of the flasks. Cultures were unialgal and sterile techniques were employed in order to avoid bacterial contamination.

Two separate experiments were performed:

(1) Diel periodicity of $\mathrm{NO}_{3}{ }^{-}$uptake rate and other physiological characteristics in a 14:10 h L:D cycle in the absence of $\mathrm{NH}_{4}{ }^{+}$. During a $24 \mathrm{~h}$ period, samples were drawn every $3 \mathrm{~h}$ from triplicate cultures for the determination of cell number, cell volume, in vivo fluorescence, chlorophyll a (chl a), particulate nitrogen 
(PN), particulate carbon (PC), and dissolved $\mathrm{NO}_{3}^{-}$concentrations. Nitrate uptake rates (fmol $\mathrm{NO}_{3}{ }^{-} \mathrm{cell}^{-1} \mathrm{~h}^{-1}$ ) were calculated for each 3 h period from the disappearance of $\mathrm{NO}_{3}{ }^{-}$from the medium and then normalized to the average cell number over the same period. Ammonium concentration was also measured, even if no additions of $\mathrm{NH}_{4}^{+}$were made.

(2) $\mathrm{NO}_{3}{ }^{-}$uptake rate with $\mathrm{NH}_{4}{ }^{+}$additions. These experiments were carried out by adding $\mathrm{NH}_{4}^{+}$to the $\mathrm{NO}_{3}{ }^{-}$-grown cultures of Emiliania huxleyi and monitoring the concentrations of $\mathrm{NO}_{3}{ }^{-}$and $\mathrm{NH}_{4}{ }^{+}$in the medium. Ammonium additions to multiple cultures ranged from 0 (control) to ca $3 \mu \mathrm{M}$. Immediately after the $\mathrm{NH}_{4}{ }^{+}$addition, samples were drawn for the determination of cell number, cell volume, in vivo fluorescence, chl a, PN, PC, and dissolved $\mathrm{NO}_{3}{ }^{-}$and $\mathrm{NH}_{4}{ }^{+}$ concentrations. Cultures were re-sampled for the same measurements every $24 \mathrm{~h}$ for 5 to $7 \mathrm{~d}$ until $24 \mathrm{~h}$ after $\mathrm{NH}_{4}{ }^{+}$became undetectable $(<0.05 \mu \mathrm{M})$. Nitrate uptake rates (fmol $\mathrm{NO}_{3}^{-}$cell-1 $\mathrm{d}^{-1}$ ) were estimated from the disappearance of $\mathrm{NO}_{3}^{-}$from the medium over $24 \mathrm{~h}$ normalized to the average cell number over that period. The concentration of $\mathrm{NH}_{4}{ }^{+}$for the same $24 \mathrm{~h}$ period was calculated as the average between the beginning and the final concentrations. Replicate cultures were run simultaneously as well as staggered in time.

Analytical methods. Growth rate was calculated as the slope of the natural log of cell number versus time, and of the natural log of in vivo fluorescence versus time. Cell numbers and average cell volumes were

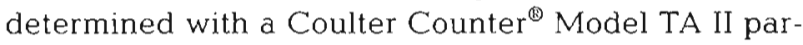
ticle counter equipped with a population accessory using a $70 \mu \mathrm{m}$ aperture. Before making measurements with the Coulter Counter ${ }^{\star}$, the $\mathrm{pH}$ of the sample was decreased to ca 5 with $5 \% \mathrm{HCl}$ to dissolve the coccoliths, which interfere with cell counts in some of the channels (Muggli \& Harrison 1996). In vivo fluorescence was measured with a Turner Designs ${ }^{\text {TM }}$ Model 10-AU fluorometer.

Samples for chl a, PN and PC (including coccoliths) were filtered through pre-combusted Whatman ${ }^{\otimes} \mathrm{GF} / \mathrm{F}$ filters (ca $0.7 \mu \mathrm{m}$ nominal porosity) using a vacuum pressure differential of $<125 \mathrm{~mm} \mathrm{Hg}$, and stored at $-20^{\circ} \mathrm{C}$ in a desiccator until analysis. Chl a was measured using in vitro fluorometry with a Turner Designs $^{\mathrm{TM}}$ Model 10-AU fluorometer (Parsons et al. 1984). After drying at $60^{\circ} \mathrm{C}, \mathrm{PN}$ and $\mathrm{PC}$ samples were analysed with a Carlo Erba Model NA-1500 Elemental Analyzer (Verardo et al. 1990).

Samples for dissolved $\mathrm{NH}_{4}{ }^{+}$and $\mathrm{NO}_{3}{ }^{-}$were gently filtered through pre-combusted Whatman ${ }^{\circledR} \mathrm{GF} / \mathrm{F}$ filters into acid-clean polypropylene bottles and processed immediately or kept at $4^{\circ} \mathrm{C}$ until analysis within a few hours. Ammonium and $\mathrm{NO}_{3}{ }^{-}$concentrations were mea- sured colorimetrically with a Technicon Autoanalyzer ${ }^{(}$ II following the procedures of Slawyk \& MacIsaac (1972) and Wood et al. (1967), respectively.

Nitrate uptake rates were estimated from the disappearance of $\mathrm{NO}_{3}^{-}$from the medium, as explained above. Due to the length of the period over which the rates were calculated ( $3 \mathrm{~h}$ in Expt 1 and $24 \mathrm{~h}$ in Expt 2), the term 'uptake' includes transport of nitrogen through the membrane and also assimilation into amino acids and proteins (i.e. growth). Efforts were made to carry out short-term measurements in Expt 2, but, due to the relatively low biomass of the cultures, nutrient disappearance was more precisely calculated over a $24 \mathrm{~h}$ period.

Models. The $\mathrm{NO}_{3}{ }^{-}$uptake rate versus $\mathrm{NH}_{4}{ }^{+}$concentration data were modeled using 2 non-linear leastsquares fits:

(1) a modified Michaelis-Menten equation of the form:

$$
\mathrm{VNO}_{3}{ }^{-}=V_{\max }-\left(\frac{V_{\max } I_{\mathrm{rnax}} \cdot \mathrm{NH}_{4}^{+}}{K_{1}+\mathrm{NH}_{4}{ }^{+}}\right)
$$

where $\mathrm{VNO}_{3}{ }^{-}$is the $\mathrm{NO}_{3}^{-}$uptake rate (fmol $\mathrm{NO}_{3}{ }^{-}$ cell ${ }^{-1} \mathrm{~d}^{-1}$ ); $V_{\text {max }}$ is the maximum rate of $\mathrm{NO}_{3}^{-}$uptake at undetectable $\mathrm{NH}_{4}{ }^{+}$concentrations (fmol $\mathrm{NO}_{3}^{-} \mathrm{cell}^{-1}$ $\mathrm{d}^{-1}$ ); $I_{\max }$ is the maximum realized inhibition (values from 0 to 1 ); $K_{i}$ is the $\mathrm{NH}_{4}{ }^{+}$concentration at which $V_{\text {max }}$ is reduced by half $(\mu \mathrm{M})$; and $\mathrm{NH}_{4}{ }^{+}$is the $\mathrm{NH}_{4}{ }^{+}$ concentration ( $\mu \mathrm{M})$.

(2) a simple exponential model of the form:

$$
V \mathrm{NO}_{3}{ }^{-}=A+B \cdot e^{-C \mathrm{NH}_{4}{ }^{+}}
$$

where $A+B$ is $V_{\max } C$ is the exponential decay constant; and $\mathrm{VNO}_{3}{ }^{-}$and $\mathrm{NH}_{4}{ }^{+}$are as above.

\section{RESULTS}

\section{Growth rate of Emiliania huxleyi}

Under the experimental conditions, the growth rate of Emiliania huxleyi was $0.75 \pm 0.02$ divisions $\mathrm{d}^{-1}$ (mean $\pm 1 \mathrm{SE}, \mathrm{n}=52$ ) when calculated from cell numbers and was not significantly different from the growth rate $\left(0.70 \pm 0.01 \mathrm{~d}^{-1}\right.$; mean $\left.\pm 1 \mathrm{SE}, \mathrm{n}=55\right) \mathrm{cal}$ culated from in vivo fluorescence ( $t$-test, $p>0.01$ ).

\section{Diel periodicity of $\mathrm{NO}_{3}{ }^{-}$uptake rate and other physiological parameters in Emiliania huxleyi}

Nitrate concentrations in the culture medium showed a more rapid decrease during the $14 \mathrm{~h}$ light period than during the $10 \mathrm{~h}$ dark period (Fig. 1). The slopes of $\mathrm{NO}_{3}{ }^{-}$disappearance for the periods $0-3$ and 


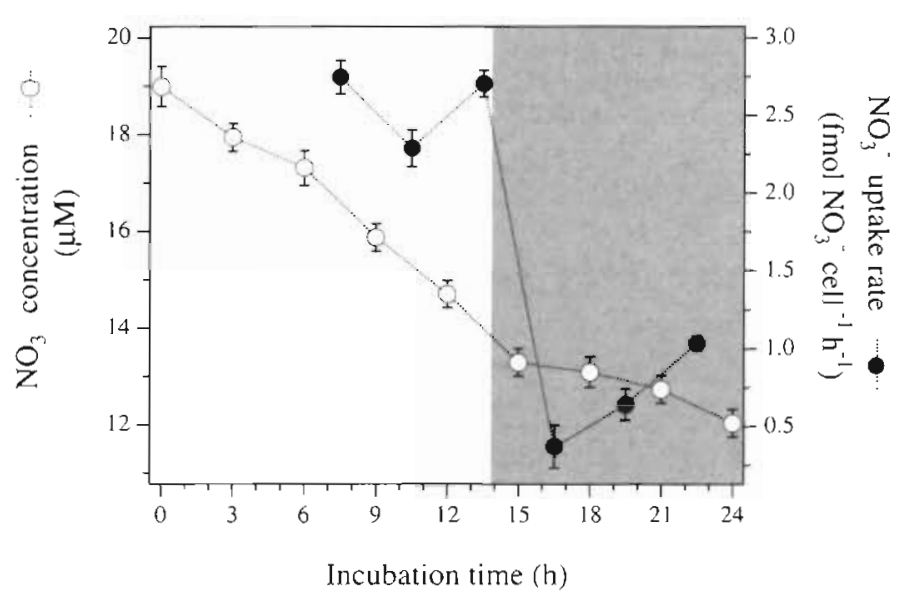

Fig. 1. Changes in nitrate concentration and nitrate uptake rate (calculated for each $3 \mathrm{~h}$ period, starting at $6 \mathrm{~h}$; see text for details) for Emiliania huxleyi cultures during a 14:10 h L:D cycle. The gray area (14 to $24 \mathrm{~h}$ ) indicates the dark period. Each symbol represents the mean of triplucate cultures $\pm 1 \mathrm{SE}$. If no error bars are visible, they are smaller than the symbol dark (Fig. 2B). As a result of these diel patterns of cell numbers and in vivo fluorescence, fluorescence per cell increased during the light period, but decreased during the dark (Fig. 2C).

$\mathrm{Chl} a$ increased constantly in the cultures, while the rate of accumulation of $\mathrm{PN}$ and $\mathrm{PC}$ was higher during the day than during the night (data not shown). When these parameters were expressed as cell quotas (Fig. 2D to F), they all showed a similar pattern of increase during the light period and decrease during the dark. Cell volume also increased during the light hours, but decreased at night (Fig. 2G).

\section{Effect of increasing $\mathrm{NH}_{4}{ }^{+}$concentrations on $\mathrm{NO}_{3}{ }^{-}$ uptake rate in Emiliania huxleyi}

Increasing $\mathrm{NH}_{4}{ }^{+}$concentrations resulted in a decrease in $\mathrm{NO}_{3}^{-}$uptake rates (Fig. 3). When $\mathrm{NH}_{4}^{+}$
3-6 $\mathrm{h}$ were lower than the slopes from 6-15 h (Fig. 1), likely due to the presence of $\mathrm{NH}_{4}^{+}$(see next section) as well as lower culture biomass (see Fig. 2B). Ammonium concentrations of $0.1 \mu \mathrm{M}$ were measured during the first $6 \mathrm{~h}$ of the experiment. However, for the rest of the incubation period, $\mathrm{NH}_{4}{ }^{+}$was undetectable $(<0.05 \mu \mathrm{M})$. Because the objective of this experiment was to determine the diel variability of $\mathrm{NO}_{3}{ }^{-}$uptake in the absence of $\mathrm{NH}_{4}{ }^{+}$, only $\mathrm{NO}_{3}{ }^{-}$uptake rates from 6 to $24 \mathrm{~h}$ are shown in Fig. 1. Cellspecific $\mathrm{NO}_{3}{ }^{-}$uptake rates were significantly higher during the light period $\left(2.53 \pm 0.04 \mathrm{fmol} \mathrm{NO}_{3}{ }^{-} \mathrm{cell}^{-1} \mathrm{~h}^{-1}\right.$; mean $\pm 1 \mathrm{SE})$ than during the dark period $\left(0.69 \pm 0.02\right.$ fmol $\mathrm{NO}_{3}{ }^{-}$cell ${ }^{-1}$ $\mathrm{h}^{-1}$, mean $\left.\pm 1 \mathrm{SE}\right)($ t-test, $\mathrm{p} \ll 0.001)$. Thus, in a $14: 10 \mathrm{~h} \mathrm{L:D} \mathrm{cycle,} 84 \%$ of the total daily $\mathrm{NO}_{3}$ was taken up during the light period, and the remaining $16 \%$ during the dark period.

During the L:D cycle, other physiological parameters were also measured (Fig. 2). Cell numbers showed a rapid increase during the last part of the dark period, but remained constant during most of the light period and the first $4 \mathrm{~h}$ of darkness (Fig. 2A). In contrast, in vivo fluorescence increased during the light period but changed little during the
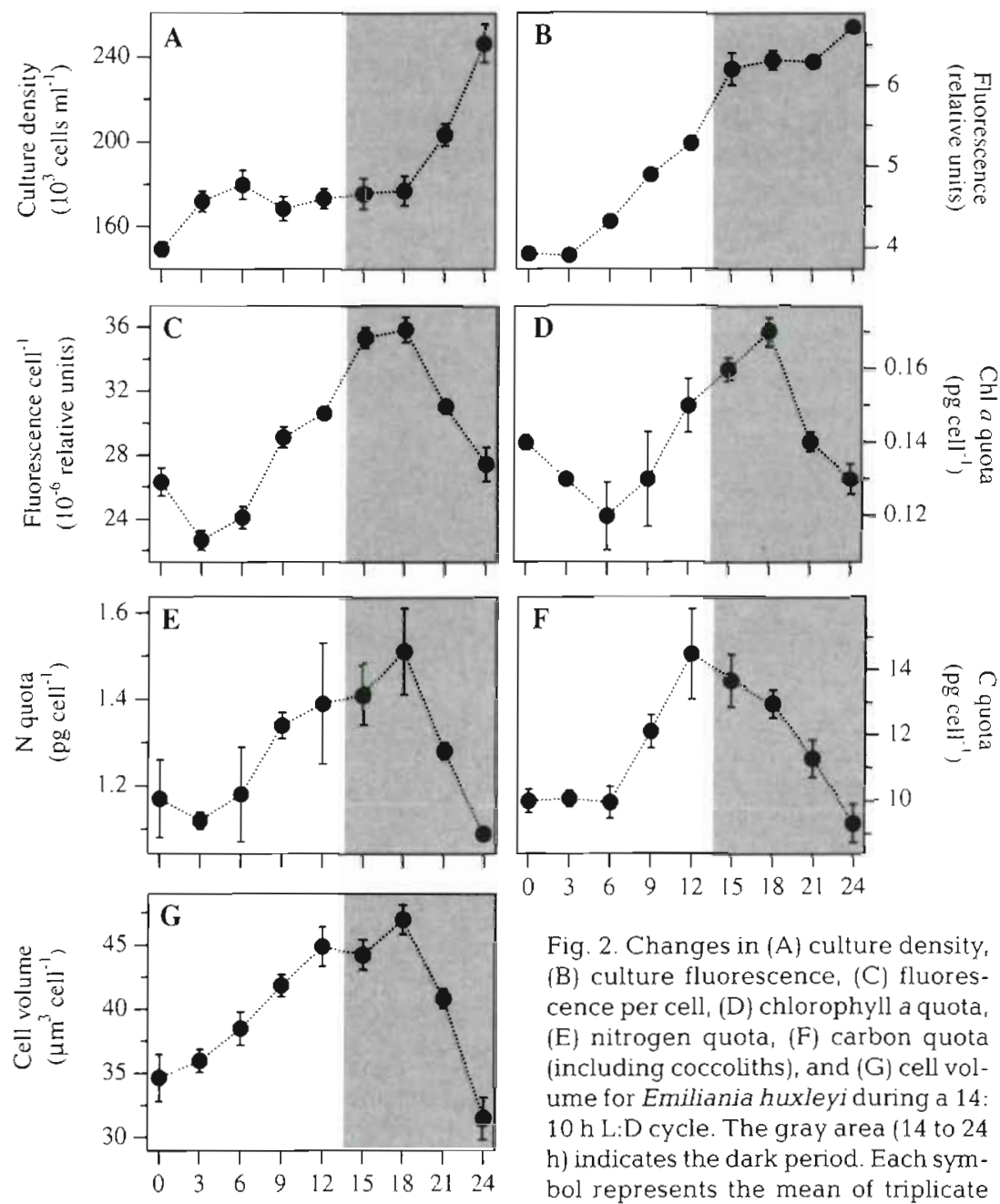

$\begin{array}{lllllllll}0 & 3 & 6 & 9 & 12 & 15 & 18 & 21 & 24\end{array}$

Fig. 2. Changes in (A) culture density, (B) culture fluorescence, (C) fluorescence per cell, (D) chlorophyll a quota, (E) nitrogen quota, (F) carbon quota (including coccoliths), and (G) cell volume for Emiliania huxleyi during a 14: $10 \mathrm{~h} \mathrm{~L}:$ D cycle. The gray area (14 to 24 h) indicates the dark period. Each symbol represents the mean of triplicate cultures $\pm 1 \mathrm{SE}$. If no error bars are vis-

Incubation time (h) ible, they are smaller than the symbol 


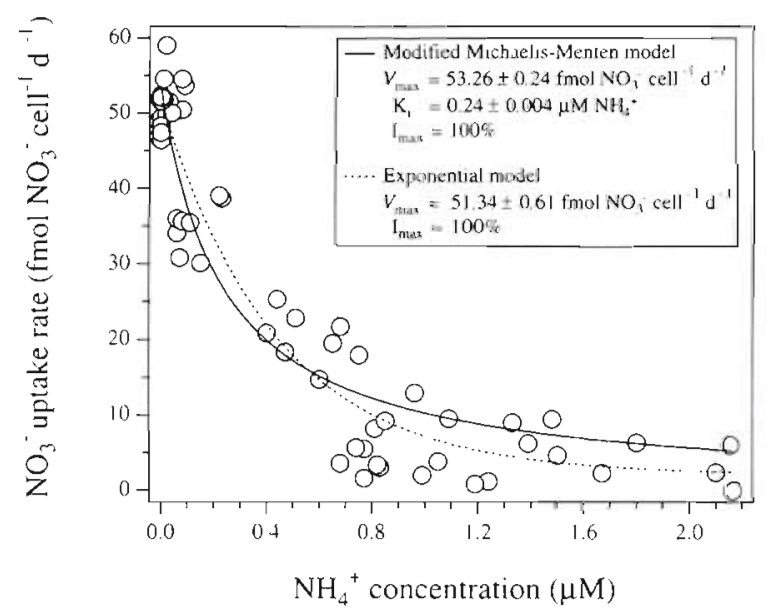

Fig. 3. Nitrate uptake rate at increasing ammonium concentrations for cultures of Emiliania huxleyi grown in a 14:10 h L:D cycle. Each symbol represents a determination from a single culture $(n=56)$. The models applied to the data as well as the fitted parameters ( $\pm 1 \mathrm{SE}$ ) are also included

concentrations were undetectable in the culture medium, $\mathrm{NO}_{3}{ }^{-}$was taken up at maximal rates; however rates decreased sharply when $\mathrm{NH}_{4}{ }^{+}$was present even at low concentrations $(<0.5 \mu \mathrm{M})$, and was almost completely inhibited at $2.2 \mu \mathrm{M} \mathrm{NH}_{4}{ }^{+}$.

With the modified Michaelis-Menten model, the best fit to the data $(\mathrm{n}=56)$ yielded a $V_{\max }( \pm \mathrm{SE})$ of $52.00 \pm$ $0.22 \mathrm{fmol} \mathrm{NO}_{3}{ }^{-}$cell $^{-1} \mathrm{~d}^{-1}$, a $K_{i}( \pm 1 \mathrm{SE})$ of $0.42 \pm 0.01 \mu \mathrm{M}$ $\mathrm{NH}_{4}{ }^{+}$, and an $I_{\text {max }}( \pm \mathrm{SE})$ of $1.2 \pm 0.01$. Since experimental values showed maximum inhibition of up to $100 \%$ and the theoretical range for $I_{\max }$ is from 0 to 1 ( 0 to $100 \%$ inhibition), the model was run again constraining $I_{\max }$ to 1 . When $I_{\max }=1$, the estimates of $V_{\max }$ and $K_{1}$ were $53.26 \pm 0.24 \mathrm{fmol} \mathrm{NO}_{3}^{-} \mathrm{cell}^{-1} \mathrm{~d}^{-1}$ and 0.24 $\pm 0.004 \mu \mathrm{M} \mathrm{NH}_{4}{ }^{+}$, respectively.

The exponential model estimated $A=2.10 \pm 0.30$, $B=49.24 \pm 0.32$ and $C=2.28 \pm 0.34$ (mean $\pm \mathrm{SE}, \mathrm{n}=$ 56). Thus, $V_{\max }(A+B)$ was $51.34 \pm 0.61 \mathrm{fmol} \mathrm{NO}_{3}^{-} \mathrm{cell}^{-1}$ $\mathrm{d}^{-1}$ and $I_{\max }$ was approximately $100 \%(A /[A+B])$. The estimates from the exponential fit were in good agreement with those from the modified Michaelis-Menten model.

\section{DISCUSSION}

Over the 5 yr period since Emiliania huxleyi was isolated, much care has been taken to maintain this isolate under conditions typical of the oceanic NE Pacific in order to avoid adaptation to unrealistic culture conditions. Physiological parameters of E. huxleyi measured during the present study were in close agreement with the measurements made soon after its isolation (Muggli \& Harrison 1996).

\section{Diel periodicity of $\mathrm{NO}_{3}{ }^{-}$uptake rate and other physiological parameters in Emiliania huxleyi}

All the physiological characteristics measured in Emiliania huxleyi showed diel changes during a 14:10 h $\mathrm{L}: \mathrm{D}$ cycle. The stimulation of $\mathrm{NO}_{3}{ }^{-}$utilization by light is thought to be primarily at the assimilation rather than at the transport level (see Vincent 1992). The higher rate of $\mathrm{NO}_{3}{ }^{-}$uptake observed here for $E$. huxleyi during the light period is likely the result of the dependency of the $\mathrm{NO}_{3}{ }^{-}$-assimilating enzymes on photosynthetic energy. Data from Eppley et al. (1971) confirm this suggestion; they found that the activity of $\mathrm{NO}_{3}{ }^{-}$ (NR) and $\mathrm{NO}_{2}^{-}$reductases measured in cell-free extracts of $E$. huxleyi was higher during day than night. These results have also been observed for other algal groups (see Syrett 1981). Berges et al. (1995) reported that diel patterns of NR activity closely followed changes in nitrogen uptake rate under high light in the diatom Thalassiosira pseudonana. The diel pattern of $\mathrm{NO}_{3}{ }^{-}$uptake rate observed by Berges et al. (1995) closely resembles the pattern shown in this study for E. huxleyi.

The diel periodicity of $\mathrm{NO}_{3}{ }^{-}$uptake rate and $\mathrm{NR}$ activity observed in laboratory studies is supported by field experiments (e.g. Eppley et al. 1970, Cochlan et al. 1991a,b, Berges et al. 1995). In the oceanic subarctic NE Pacific, phytoplankton $\mathrm{NO}_{3}^{-}$uptake rates showed a clear diel pattern, with daytime rates about twice nighttime values (Cochlan et al. 1991a). A similar pattern was also reported by Wheeler et al. (1989) and Wheeler \& Kokkinakis (1990). Although NR activity was not measured in the subarctic NE Pacific, diel variations would probably show patterns similar to those found by Cochlan et al. (1991a) for $\mathrm{NO}_{3}{ }^{-}$uptake rates.

The nocturnal synchronization of cell division observed during the present study has been reported previously for other isolates of Emiliania huxleyi (e.g. Paasche 1967, Nelson \& Brand 1979, Van Bleijswijk et al. 1994) as well as for other algal species (e.g. Nelson \& Brand 1979, Berdalet et al. 1992). Of all the algal groups, the most complex and varied patterns of diel periodicity in cell number have been exhibited by diatoms. Diatom division rates have been shown to increase in the light (Nelson \& Brand 1979, Chisholm \& Costello 1980), in the dark (Eppley \& Renger 1974), in both light and dark periods (Chisholm \& Costello 1980 ), or to remain constant over the L:D cycle (Nelson \& Brand 1979, Berges et al. 1995).

The diel pattern of in vivo fluorescence, fluorescence per cell and cell volume observed by Van Bleijswijk et al. (1994) and of chl a per cell reported by Paasche (1967) for other isolates of Emiliania huxleyi coincided with the findings of this study. When comparing the diel periodicity of cell volume of $E$. huxleyi with those 
of diatom species, more complex patterns are observed for diatoms, with 2 peaks found during the $24 \mathrm{~h}$ diel period (e.g. Berges et al. 1995) as opposed to 1 for E. huxleyi

The strong diel periodicity in $\mathrm{NO}_{3}{ }^{-}$uptake rates and other physiological characteristics for Emiliania huxleyi required a $24 \mathrm{~h}$ sampling interval during the $\mathrm{NO}_{3}{ }^{-}-$ $\mathrm{NH}_{4}{ }^{+}$uptake interaction experiment.

\section{Effect of $\mathrm{NH}_{4}{ }^{+}$on $\mathrm{NO}_{3}{ }^{-}$uptake rate}

Results from this study suggest an inhibitory effect of $\mathrm{NH}_{4}{ }^{+}$on $\mathrm{NO}_{3}{ }^{-}$uptake in the subarctic isolate of Emiliania huxleyi. Maximal $\mathrm{NO}_{3}^{-}$uptake rates at undetectable concentrations of $\mathrm{NH}_{4}{ }^{+}$were rapidly reduced when $\mathrm{NH}_{4}{ }^{+}$was present. Although inhibition of $\mathrm{NO}_{3}$ uptake by $\mathrm{NH}_{4}{ }^{+}$has been observed in many laboratory studies on unialgal cultures of phytoplankton (see Dortch 1990), this is the first study to investigate this phenomenon for any phytoplankton species isolated from a HNLC region.

The culture conditions adopted in the present study for Emiliania huxleyi were very similar to those found in the surface waters of the oceanic subarctic NE Pacific during the summer period, in terms of temperature, photoperiod and composition of the medium, and thus, extrapolation to a field scenario is reasonable. Cochlan \& Harrison (1991) also simulated natural conditions as close as possible when studying nitrogen uptake interactions in the picoplanktonic alga Micromonas pusilla, and found that $\mathrm{NO}_{3}{ }^{-}$uptake rate was completely inhibited at $1 \mu \mathrm{M} \mathrm{NH}{ }_{4}{ }^{+}$. Maximal uptake rate of $\mathrm{NO}_{3}{ }^{-}$was only obtained when $\mathrm{NH}_{4}{ }^{+}$was exhausted from the medium. Similar findings were reported for more commonly used species such as Chlorella vulgaris (e.g. Syrett \& Morris 1963), Skeletonema costatum (e.g. Bates 1976, Dortch \& Conway 1984), and Thalassiosira pseudonana (e.g. Dortch et al. 1991, Berges et al. 1995, Yin et al. 1998).

In all of the above studies, significant or complete inhibition of $\mathrm{NO}_{3}{ }^{-}$uptake was observed between 0.5 and $1 \mu \mathrm{M} \mathrm{NH}_{4}{ }^{+}$. In the isolate of Emiliania huxleyi studied here inhibition at 0.5 and $1 \mu \mathrm{M} \mathrm{NH}_{4}{ }^{+}$was ca 68 and $81 \%$ (derived from the Michaelis-Menten model), respectively, and complete inhibition was not achieved below $2.2 \mu \mathrm{M}$. Differences between laboratory studies are not uncommon because inhibition is species specific and is also affected by the preconditioning of the cultures (e.g. Dortch \& Conway 1984, Dortch et al. 1991), light levels (e.g. Bates 1976, Yin et al. 1998) and other environmental factors, such as temperature (Lomas \& Glibert 1999). Thus, multiple responses can be expected from different laboratory studies and, principally, from the field.
The extrapolation of the response by unialgal cultures of phytoplankton in the laboratory to that by a natural assemblage of phytoplankton in the field is problematic. However, laboratory experimentation is still a powerful approach for studying phytoplankton physiology, which would be difficult to assess in the field, where the physiological responses of phytoplankton assemblages are a product of the compounding effects of environmental parameters and the response by individual species. In the subarctic NE Pacific, Varela \& Harrison (1999) showed that at ambient $\mathrm{NH}_{4}{ }^{+}$concentration $<0.5 \mu \mathrm{M}$ the $\mathrm{N}$-specific uptake rate of $\mathrm{NO}_{3}{ }^{-}$by the natural assemblages of phytoplankton varied widely, indicating that factors other than the absolute concentration of $\mathrm{NH}_{4}{ }^{+}$, i.e. irradiance and/or iron levels (La Roche et al. 1996), are affecting these rates. At $\mathrm{NH}_{4}^{+}>0.5 \mu \mathrm{M}, \mathrm{NO}_{3}{ }^{-}$uptake rates were lower, however those rates corresponded to low light levels (Varela \& Harrison 1999). Although limiting iron and irradiance levels may have accounted for the low rates in the Varela \& Harrison (1999) study, compounding inhibitory effects of $\mathrm{NH}_{4}{ }^{+}$on $\mathrm{NO}_{3}{ }^{-}$uptake cannot be disregarded.

Field studies on natural phytoplankton assemblages have suggested that $\mathrm{NH}_{4}{ }^{+}$inhibition of $\mathrm{NO}_{3}{ }^{-}$uptake commonly occurs in the oceans (e.g. McCarthy et al. 1975, Blasco \& Conway 1982, Cochlan 1986, Wheeler \& Kokkinakis 1990, Muggli \& Smith 1993, Harrison et al. 1996). Wheeler \& Kokkinakis (1990) presented the first evidence of a $\mathrm{NH}_{4}{ }^{+}-\mathrm{NO}_{3}{ }^{-}$interaction in the oceanic $\mathrm{NE}$ Pacific. They indicated that $\mathrm{NO}_{3}{ }^{-}$assimilation was completely inhibited at 0.1 to $0.3 \mu \mathrm{M} \mathrm{NH}_{4}{ }^{+}$, and the shape of the relationship was linear. The results obtained for Emiliania huxleyi in this laboratory experiment agree in that a negative relationship exists. However, inhibition of $\mathrm{NO}_{3}^{-}$uptake was never complete for E. huxleyi at concentrations as low as 0.1 to $0.3 \mu \mathrm{M} \mathrm{NH}_{4}{ }^{+}$and the relationship was non-linear. It was observed, however, that at $0.24 \mu \mathrm{M} \mathrm{NH}_{4}{ }^{+}, \mathrm{NO}_{3}{ }^{-}$ uptake rate by $E$. huxleyi was reduced to $50 \%$ of its maximal rate and that the rate only reached undetectable values at $2.2 \mu \mathrm{M} \mathrm{NH}_{4}{ }^{+}$. Although the results of the present study and those of Wheeler \& Kokkinakis (1990) do not entirely agree, both studies demonstrate that a suppression of $\mathrm{NO}_{3}{ }^{-}$uptake occurs both in subarctic waters and in cultures of a phytoplankton species isolated from this region.

\section{Ecological implications}

On the basis of the findings of this laboratory study on Emiliania huxleyi, inhibition of $\mathrm{NO}_{3}{ }^{-}$uptake by $\mathrm{NH}_{4}{ }^{+}$may be one of the factors contributing to the low rates of $\mathrm{NO}_{3}^{-}$uptake in surface waters of the oceanic 


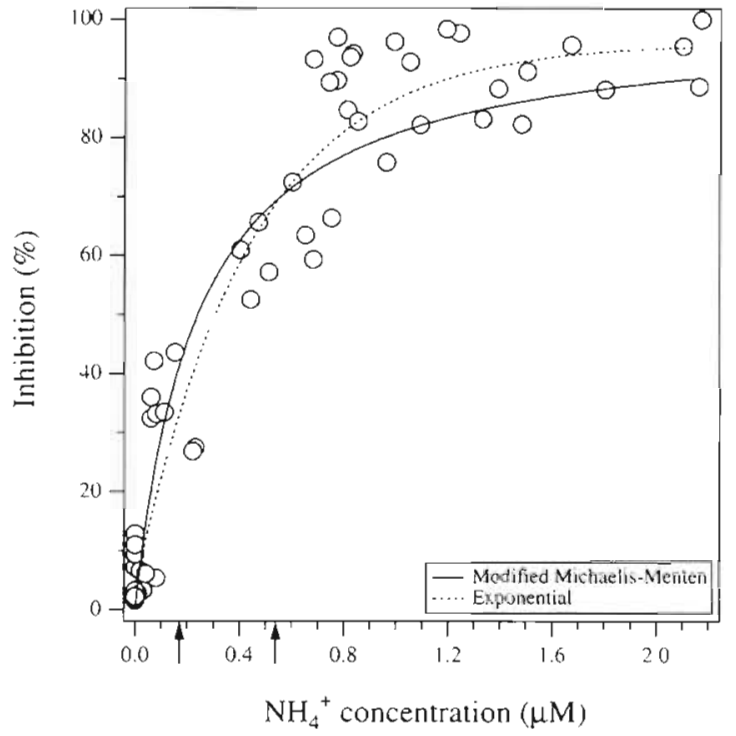

Fig. 4. Percent inhibition of nitrate uptake rate at increasing ammonium concentrations for cultures of Emiliania huxleyi grown in a 14:10 h L:D cycle. Same data as used in Fig. 3 but transformed to percentages. Each symbol represents a determination from a single culture $(n=56)$. The models used to fit the data are also included. Arrows point to minimum and maximum ammonium concentrations measured at OSP in the NE Pacific during 1992 to 1994 by Varela \& Harrison (1999)

subarctic NE Pacific during those times of the year when temperature and irradiance are saturating for growth.

Although it has been shown that $\mathrm{NO}_{3}^{-}$uptake rates by phytoplankton in the oceanic NE Pacific may be impaired by iron limitation (e.g. Martin \& Fitzwater 1988, Boyd et al. 1996), this was only the case for cells $>5 \mu \mathrm{m}$ (Boyd et al. 1996). Iron enrichment did not affect the $\mathrm{N}$-specific uptake rates of $\mathrm{NO}_{3}{ }^{-}$by phytoplankton cells $<5 \mu \mathrm{m}$ (Boyd et al. 1996). In addition, laboratory results on $\mathrm{NO}_{3}^{-}$-grown Emiliania huxleyi demonstrated that under the low iron concentrations typical of OSP growth rate was not limited; E. huxleyi reduced its requirements for photosynthate and iron by decreasing its cell volume (Muggli \& Harrison 1996). This field and laboratory evidence suggests that during the summer, $\mathrm{NO}_{3}{ }^{-}$uptake in the $<5 \mu \mathrm{m}$ size-fraction is not impaired by low iron levels. However, the specific uptake rate of $\mathrm{NO}_{3}^{-}$by the small cells at OSP is still low (Varela 1997), implying that some limitation is still imposed on $\mathrm{NO}_{3}{ }^{-}$uptake in the small cells. This laboratory experiment suggests that the constant availability of $\mathrm{NH}_{4}{ }^{+}$in oceanic waters of the NE Pacific may be partly responsible for these depressed $\mathrm{NO}_{3}{ }^{-}$uptake rates.

The impact of this $\mathrm{NH}_{4}{ }^{+}-\mathrm{NO}_{3}{ }^{-}$uptake interaction in Emiliania huxleyi on the subarctic ecosystem cannot be neglected since this species forms part of the domi- nant size class $(<5 \mu \mathrm{m})$ of this region. The degree to which the utilization of $\mathrm{NO}_{3}{ }^{-}$is prevented in the small phytoplankton size class will depend on the $\mathrm{NH}_{4}{ }^{+}$concentration present in the water. This laboratory experiment suggests inhibition of $\mathrm{NO}_{3}{ }^{-}$uptake rate by $\mathrm{NH}_{4}{ }^{+}$ of between 38 and $70 \%$ (Fig. 4) at the range of $\mathrm{NH}_{4}^{+}$ levels ( 0.17 to $0.54 \mu \mathrm{M}$, respectively) measured at OSP (Varela \& Harrison 1999). This may partly contribute to the low $f$-ratios $(0.27$ on average) found at OSP throughout the water column at various times of the year (Varela \& Harrison 1999).

Acknowledgements. We extend our appreciation to D. Crawford, T. Larson, R. Guy, F. Whitney, T Parsons and S. Calvert for comments on the manuscript and to $M$. Soon for PN/PC values. We also thank 3 anonymous reviewers for their valuable comments. D.E.V. was supported by UBC University Graduate and Chevron Fellowships.

\section{LITERATURE CITED}

Bates SS (1976) Effects of light and ammonium on nitrate uptake by two species of estuarine phytoplankton. Limnol Oceanogr 21:212-218

Berdalet $E$, Latasa M. Estrada M (1992) Variations in biochemical parameters of Heterocapsa sp. and Olisthodiscus luteus grown in 12:12 light:dark cycles. I. Cell cycle and nucleic acid composition. Hydrobiol 238:139-147

Berges JA, Cochlan WP, Harrison PJ (1995) Laboratory and field responses of algal nitrate reductase to diel periodicity in irradiance, nitrate exhaustion, and the presence of ammonium. Mar Ecol Prog Ser 124:259-269

Blasco D, Conway HL (1982) Effect of ammonium on the regulation of nitrate assimilation in natural phytoplankton populations. J Exp Mar Biol Ecol 61:157-168

Booth BC, Lewin J, Postel JR (1993) Temporal variation in the structure of autotrophic and heterotrophic communities in the subarctic Pacific. Prog Oceanogr 32:57--99

Boyd PW, Muggli DL, Varela DE, Goldblatt RH, Chretien R, Orians JK, Harrison PJ (1996) In vitro iron enrichment experiments in the NE subarctic Pacific. Mar Ecol Prog Ser 136:179-193

Brand LE (1982) Genetic variability and spatial patterns of genetic differentiation in the reproductive rates of the marine coccolithophores Emiliania huxleyi and Gephyrocapsa oceanica. Limnol Oceanogr 27:236-245

Chisholm SW, Costello JC (1980) Influence of environmental factors and population composition on the timing of cell division in Thalassiosira fluviatilis (Bacillariophyceae) grown on light/dark cycles. J Phycol 16:375-383

Cochlan WP (1986) Seasonal study of uptake and regeneration of nitrogen on the Scotian Shelf. Cont Shelf Res 5:555-577

Cochlan WP, Harrison PJ (1991) Inhibition of nitrate uptake by ammonium and urea in the eucaryotic picoflagellate Micromonas pusilla (Butcher) Manton et Parke. J Exp Mar Biol Ecol 153:143-152

Cochlan WP, Harrison PJ, Denman KL (1991a) Diel periodicity of nitrogen uptake by marine phytoplankton in nitraterich environments. Limnol Oceanogr 36:1689-1700

Cochlan WP, Price NM, Harrison PJ (1991b) Effects of irradiance on nitrogen uptake by phytoplankton: comparison of frontal and stratified communities. Mar Ecol Prog Ser 69: $103-116$ 
Dortch Q (1990) The interaction between ammonium and nitrate uptake in phytoplankton. Mar Ecol Prog Ser 61: $183-201$

Dortch Q, Conway HL (1984) Interactions between nitrate and ammonium uptake: variations with growth rate, nitrogen source and species. Mar Biol 79:151-164

Dortch Q. Thompson PA, Harrison PJ (1991) Short-term interaction between nitrate and ammonium uptake in. Thalassiosira pseudonana: effect of preconditioning nitrogen source and growth rate. Mar Biol 110:183-193

Eppley RW, Renger EH (1974) Nitrogen assimilation of an oceanic diatom in nitrogen-limited continuous culture. J Phycol 10:15-23

Eppley RW, Packard TT, MacIsaac JJ (1970) Nitrate reductase in Peru current phytoplankton. Mar Biol 6:195-199

Eppley RW, Rogers JN, McCarthy JJ (1971) Light/dark periodicity in nitrogen assimilation of the marine phytoplankters Skeletonema costatum and Coccolithus huxleyi in $\mathrm{N}$ limited chemostat culture. J Phycol 7:150-154

Frost BW (1991) The role of grazing in nutrient-rich areas of the open sea. Limnol Oceanogr 36:1616-1630

Harrison PJ, Waters RE, Taylor FJR (1980) A broad spectrum artificial seawater medium for coastal and open ocean phytoplankton. J Phycol 16:28-35

Harrison WG, Harris LR, Irwin BD (1996) The kinetics of nitrogen utilization in the oceanic mixed layer: nitrate and ammonium interactions at nanomolar concentrations. Limnol Oceanogr 41:16-32

Honjo S, Okada H (1974) Community structure of coccolithophores in the photic layer of the mid-Pacific. Micropaleontology 20:209-230

Keller MD, Bellows WK, Guillard RRL (1989) Dimethyl sulfide production in marine phytoplankton. In: Saltzman ES, Cooper WJ (eds) Biogenic sulfur in the environment. Am Chem Soc Symp Ser 393. American Chemical Society, Washington, DC, p 167-182

Kokkinakis SA, Wheeler PA (1987) Nitrogen uptake and phytoplankton growth in coastal upwelling regions. Limnol Oceanogr 32:1112-1123

Kristiansen S, Lund BA (1989) Nitrogen cycling in the Barents Sea-I. Uptake of nitrogen in the water column. DeepSea Res 36:255-268

La Roche J, Boyd PW, McKay RML, Geider RJ (1996) Flavodoxin as an in situ marker for iron stress in phytoplankton Nature 382:802-805

Lecourt M, Muggli DL, Harrison PJ (1996) Comparison of growth and sinking rates of non-coccolith-and coccolithforming strains of Emiliania huxleyi (Prymnesiophyceae) grown under different irradiances and nitrogen sources. J Phycol 32:17-21

Lomas $\mathrm{MW}$, Glibert PM (1999) Interactions between $\mathrm{NH}_{4}{ }^{+}$ and $\mathrm{NO}_{3}{ }^{-}$uptake and assimilation: comparison of diatoms and dinoflagellates at several growth temperatures. Mar Bjol 133:541-551

Martin JH, Fitzwater SE (1988) Iron deficiency limits phytoplankton growth in the north-east Pacific subarctic Nature 331:341-343

McCarthy JJ, Taylor WR, Taft JL (1975) The dynamics of nitrogen and phosphorus cycling in the open waters of the Chesapeake Bay. In: Church TM (ed) Marine chemistry in the coastal environment. Am Chem Soc Symp Ser 18. American Chemical Society, Washington, DC, p 664-681

Miller CB, Frost BW, Wheeler PA, Landry MR, Welschmeyer $N$, Powell TM (1991) Ecological dynamics in the subarctic Pacific, a possibly iron-limited ecosystem. Limnol Oceanogr 36:1600-1615

Muggli DL (1995) Effects of iron on the physiology of oceanic phytoplankton from the NE subarctic Pacific Ocean. PhD thesis, Dept of Oceanography, University of British Columbia, Vancouver

Muggli DL, Harrison PJ (1996) Effects of nitrogen source on the physiology and metal nutrition of Emiliania huxleyi grown under different iron and light conditions. Mar Ecol Prog Ser 130:255-267

Muggli DL, Smith WO Jr (1993) Regulation of nitrate and ammonium uptake in the Greenland Sea. Mar Biol 115: $199-208$

Nelson DM, Brand LE (1979) Cell division periodicity in 13 species of marine phytoplankton on a light:dark cycle. J Phycol 15:67-75

Paasche, E (1967) Marine plankton algae grown with lightdark cycles. I. Coccolithus huxleyi. Physiol Plant 20: 946-956

Parsons TR, Maita Y, Lalli CM (1984) A manual of chemical and biological methods for seawater analysis. Pergamon Press, Oxford

Sikes CS, Fabry VJ (1994) Photosynthesis, $\mathrm{CaCO}_{3}$ deposition, coccolithophorids, and the global carbon cycle. In: Tolbert $\mathrm{NE}$, Preiss $\mathrm{J}$ (eds) Regulation of atmospheric $\mathrm{CO}_{2}$ and $\mathrm{O}_{2}$ by photosynthetic carbon metabolism. Oxford University Press, New York, p 217-233

Slawyk G, MacIsaac JJ (1972) Comparison of two automated ammonium methods in a region of coastal upwelling. Deep-Sea Res 19:521-524

Syrett PJ (1981) Nitrogen metabolism of microalgae. In: Platt $\mathrm{T}$ (ed) Physiological bases of phytoplankton ecology. Can Bull Fish Aquat Sci 210:182-210

Syrett PJ, Morris I (1963) The inhibition of nitrate assimilation by ammonium in Chlorella. Biochim Biophys Acta 67 : 566-575

Taylor FJR, Waters RE (1982) Spring phytoplankton in the subarctic North Pacific Ocean. Mar Biol 67:323-335

Van Bleijswijk JDL, Kempers RS, Veldhuis MJ (1994) Cell and growth characteristics of types $\mathrm{A}$ and $\mathrm{B}$ of Emiliania huxleyi (Prymnesiophyceae) as determined by flow cytometry and chemical analyses. J Phycol 30:230-241

Varela DE (1997) Nitrogenous nutrition of phytoplankton from the northeastern subarctic Pacific Ocean. PhD thesis, Dept of Earth of Ocean Sciences, Univ of British Columbia, Vancouver

Varela DE, Harrison PJ (1999) Seasonal variability in nitrogenous nutrition of phytoplankton assemblages in the northeastern subarctic Pacific Ocean. Deep-Sea Res II 46 : (in press)

Verardo DJ, Froelich PN, McIntyre A (1990) Determination of organic carbon and nitrogen in marine sediments using the Carlo Erba NA-1500 Analyzer. Deep-Sea Res 37: $157-165$

Vincent WF (1992) The daily pattern of nitrogen uptake by phytoplankton in dyramic mixed layer environments. Hydrobiologia 238:37-52

Wheeler PA, Kokkinakis SA (1990) Ammonium recycling limits nitrate use in the oceanic subarctic Pacific. Limnol Oceanogr 35:1267-1278

Wheeler PA, Kirchman DL, Landry MR, Kokkinakis SA (1989) Diel periodicity in ammonium uptake and regeneration in the oceanic subarctic Pacific: implications for interactions in microbial food webs. Limnol Oceanogr 34:1025-1033

Wood ED, Armstrong FAJ, Richards FA (1967) Determination of nitrate in seawater by cadmium-cooper reduction to nitrite. J Mar Biol Assoc UK 47:23-31

Yin K, Harrison PJ, Dortch Q (1998) Lack of ammonium inhibition of nitrate uptake for a diatom grown under low light conditions. J Exp Mar Biol Ecol 228:151-165 